Prepared in cooperation with the Kootenai Tribe of Idaho

\title{
Effects of Incubation Substrates on Hatch Timing and Success of White Sturgeon (Acipenser transmontanus) Embryos
}

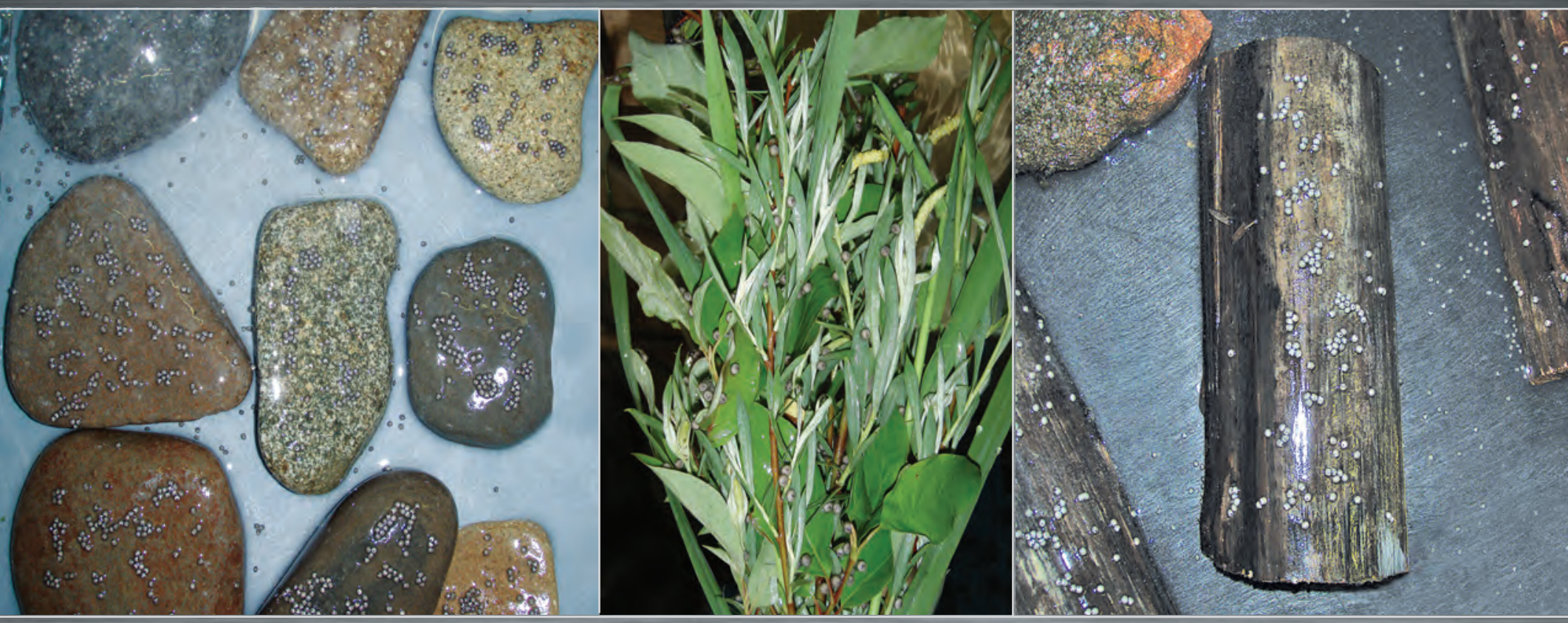

Scientific Investigations Report 2013-5180 
Cover: Photographs showing white sturgeon embryos attached to incubation substrates prior to placement into water-filled incubators. Photographs show three substrates from left to right-clean river rocks, riparian vegetation, and waterlogged wood. Photographs taken by Eric Kofoot, U.S. Geological Survey, 2007. 


\section{Effects of Incubation Substrates on Hatch Timing and Success of White Sturgeon (Acipenser transmontanus) Embryos}

By Michael J. Parsley and Eric Kofoot

Prepared in cooperation with the Kootenai Tribe of Idaho

Scientific Investigations Report 2013-5180 


\title{
U.S. Department of the Interior SALLY JEWELL, Secretary
}

\section{U.S. Geological Survey Suzette M. Kimball, Acting Director}

\author{
U.S. Geological Survey, Reston, Virginia: 2013
}

For more information on the USGS - the Federal source for science about the Earth, its natural and living resources, natural hazards, and the environment, visit http://www.usgs.gov or call 1-888-ASK-USGS.

For an overview of USGS information products, including maps, imagery, and publications, visit http://www.usgs.gov/pubprod

To order this and other USGS information products, visit http://store.usgs.gov

Any use of trade, firm, or product names is for descriptive purposes only and does not imply endorsement by the U.S. Government.

Although this information product, for the most part, is in the public domain, it also may contain copyrighted materials as noted in the text. Permission to reproduce copyrighted items must be secured from the copyright owner.

Suggested citation:

Parsley, M.J., and Kofoot, Eric, 2013, Effects of incubation substrates on hatch timing and success of White Sturgeon (Acipenser transmontanus) embryos: U.S. Geological Survey Scientific Investigations Report 2013-5180, 16 p., http://dx.doi.org/10.3133/sir20135180.

ISSN 2328-0328 (online) 


\section{Contents}

Abstract
Introduction.
Methods
Incubation Substrates.
Incubation, Hatch, and Analysis of Data
Effect of Substrate on Hatch Timing and Success
Summary
Acknowledgments
References Cited Substrate on Free-Embryo Length at Hatch
Glossary

\section{Figures}

1. Photograph showing arrangement of incubators in the $6 \times 3$ block design .......................2

2. Photograph showing an incubator with developing embryos attached to a rock typical of a substrate covered with periphyton and algae .................................................

3. Photograph showing developing embryos attached to clean river rocks typical of the substrate in many white sturgeon spawning areas....................................................

4. Photograph showing examples of the riparian vegetation used as substrates.................5

5. Photograph showing an incubator with white sturgeon embryos on a sand substrate ..6

6. Graph showing water temperatures recorded hourly in the three headboxes that supplied water to the incubation tanks........................................................................

7. Photograph showing an incubator with sturgeon embryos that had floated off the sand substrate and become lodged in the notch of the water-level control weir ............8

8. Boxplot showing total lengths of free-swimming hatched embryos from different incubation substrates. 


\section{Tables}

1. Incubation and hatch data associated with each incubator.

2. Two-way analysis of variance results for incubation substrate effects on incubation time to first hatch.

3. Tukey multiple comparisons of means of time to first hatch for each substrate ..............9

4. Two-way analysis of variance results for incubation substrate effects on incubation time to achieve 50-percent hatch.

5. Tukey multiple comparisons of means of time to achieve 50-percent hatch from each substrate

6. Two-way analysis of variance results for incubation substrate effects on proportion of hatched embryos.

7. Tukey multiple comparisons of means of the proportion of hatched embryos from each substrate

8. Number of free-swimming embryos measured for total length from each incubation substrate.

9. Two-way analysis of variance results for incubation substrate effects on total length of free-swimming hatched embryos.

10. Tukey multiple comparisons of means of total lengths of newly hatched embryos from each substrate

\section{Conversion Factors}

SI to Inch/Pound

\begin{tabular}{lcl}
\hline \multicolumn{1}{c}{ Multiply } & By & \multicolumn{1}{c}{ To obtain } \\
\hline millimeter (mm) & \multicolumn{1}{c}{ Length } & \\
millimeter (mm) & 0.03937 & inch (in.) \\
centimeter (cm) & 1,000 & micrometer $(\mu \mathrm{m})$ \\
kilometer $(\mathrm{km})$ & 0.3937 & inch (in.) \\
& 0.6214 & mile (mi) \\
\hline liter $(\mathrm{L})$ & \multicolumn{1}{c}{ Volume } & \\
milliliter $(\mathrm{mL})$ & 0.2642 & gallon (gal) \\
\hline
\end{tabular}

Temperature in degrees Celsius $\left({ }^{\circ} \mathrm{C}\right)$ may be converted to degrees Fahrenheit $\left({ }^{\circ} \mathrm{F}\right)$ as follows:

$$
{ }^{\circ} \mathrm{F}=\left(1.8 \times{ }^{\circ} \mathrm{C}\right)+32
$$




\title{
Effects of Incubation Substrates on Hatch Timing and Success of White Sturgeon (Acipenser transmontanus) Embryos
}

\author{
By Michael J. Parsley and Eric Kofoot
}

\begin{abstract}
The Kootenai River white sturgeon (Acipenser transmontanus) was listed as endangered under the Endangered Species Act in 1994 because several decades of failed spawning had put the population at risk of extinction. Natural spawning is known to occur at several locations in the Kootenai River, Idaho, but there is little natural recruitment. Microhabitat where embryo incubation occurs is known to be an important factor in white sturgeon reproductive success. This study was conducted to address questions regarding the suitability of different substrates as egg attachment and incubation sites for these fish. A comparative laboratory study using six types of incubation substrates-clean river rocks, periphyton- and algae-covered rocks, waterlogged wood, sand, riparian vegetation, and clean glass plates-tested the hypothesis that survival to hatch of white sturgeon eggs differs among incubation substrates. The results showed that sand was unsuitable as an incubation substrate, as the adhesive embryos were easily dislodged. Periphyton- and algae-covered rocks had the lowest hatch success, and all other substrates had similar hatch success.
\end{abstract}

\section{Introduction}

The Kootenai River white sturgeon (Acipenser transmontanus) was listed as endangered under the Endangered Species Act in 1994 (U.S. Fish and Wildlife Service, 1994) because of the gradual decline in adult fish that began around 1960 (Duke and others, 1999; Beamesderfer and others, 2009). The decline was caused by the failure of spawning to produce enough young sturgeon to sustain the population. Spawning by white sturgeon is known to occur at several locations over a 20-km reach in the Kootenai River, Idaho (Paragamian and others, 2001); however, production of free-swimming embryos and feeding larvae from the spawning areas is negligible. The failed spawning has been attributed to many factors including the overall loss of spawning habitat, altered river flows owing to hydropower and flood-risk mitigation (Anders and others, 2002; Paragamian and Wakkinen, 2011), and egg suffocation from accretion of fine sediments (Kock and others, 2006).

Microhabitat where egg incubation and embryonic development occur may be an important factor in white sturgeon reproductive success. White sturgeon are broadcast spawners and eggs are dispersed over the riverbed as they sink. The fertilized eggs are about $3.5 \mathrm{~mm}$ in diameter (Deng and others, 2002) and are somewhat heavier than water. The eggs have a jelly coat that becomes adhesive about 5 minutes (range 2-13 minutes; Markov, 1978) after contact with water. This jelly coat anchors the eggs to the substrate during natural spawning (Conte and others, 1988). Coutant (2004) describes what is known about the adhesion of sturgeon eggs and the role of river hydraulics on egg dispersal and quality of substrates for incubation sites. Clean, smooth surfaces generally are expected to provide better incubation sites than overly rough, "oily," and "fluffy" surfaces, which can result from periphyton or algae growth on the substrates. River hydraulics and hydrological cycles can clean substrates through scour and repeated cycles of exposure and inundation, but anthropogenic changes have moderated flows and water-surface elevation changes in many areas, which may result in "dirtier" substrates in sturgeon-egg incubation areas.

Successful sturgeon spawning and egg incubation habitat generally is composed of boulders, cobbles, gravels, or combinations of these materials. Sand currently (2013) dominates the riverbed at most known spawning areas for white sturgeon in the Kootenai River as a result of the decrease in peak flows (Barton, 2003). Sand is not considered a good substrate for spawning and subsequent incubation of sturgeon eggs (Parsley and Beckman, 1994; Kock and others, 2006), although spawning by white sturgeon does occur in areas where sand is present in the Kootenai River (Paragamian and others, 2001) and in the Fraser River (Perrin and others, 2003). Coutant (2004) suggested that low-relief overflow zones adjacent to river channels that become inundated 
with high flows during the sturgeon spawning season offer various clean substrates that sturgeon eggs can adhere. These substrates would include stones of all sizes and vegetation that would provide a meshwork of clean surfaces for attachment of eggs in clean, well-aerated water (Coutant, 2004).

The recovery plan for white sturgeon in the Kootenai River outlined a three-part strategy including implementing measures to restore natural recruitment, the use of conservation aquaculture to prevent extinction, and continued monitoring and evaluation of population trends (U.S. Fish and Wildlife Service, 1999). Efforts to increase success of natural spawning include habitat restoration projects to improve physical habitat for spawning and egg incubation. Planning for the restoration of habitat naturally led to questions regarding the suitability of different substrates as egg-attachment and incubation sites for these fish. The goal of this study was to evaluate different materials as egg-incubation media in white sturgeon spawning areas. Several hypotheses were tested to meet this goal:

- Survival to hatch of white sturgeon embryos did not differ among incubation substrates.

- Incubation period did not differ among incubation substrates.

- Incubation substrate had no effect on total lengths of newly hatched white sturgeon.

\section{Methods}

In this comparative study, six incubation substrates were tested-clean river rocks, periphyton- and algae-covered rocks, waterlogged wood, sand, riparian vegetation, and clean glass plate. All test substrates, with the exception of the clean glass plates, are present at some level in known spawning areas in the Kootenai River, Idaho. The study was conducted at the Kootenai Tribal Sturgeon Hatchery near Bonners Ferry, Idaho, and all routine broodstock capture and spawning operations were handled by hatchery personnel. Eggs and sperm were obtained from wild Kootenai River white sturgeon captured by angling. Females were held in captivity and injected with luteinizing hormone (LHRH-A) to induce ovulation. Sperm was immediately expressed from ripe males and held in refrigerated containers for later use. All fish were released back into the river after gametes were obtained.

The experiment followed a randomized block design and each substrate type $(n=6)$ constituted a treatment. Incubators were arranged in three blocks of six incubators. Each of the six incubators within a block was randomly assigned to hold a specific substrate type (fig. 1).

Incubators were constructed from glass aquariums (40.6 cm long $\times 20.3 \mathrm{~cm}$ wide $\times 25.4 \mathrm{~cm}$ deep) filled with water to a minimum depth of $18.5 \mathrm{~cm}$. A constant flow of

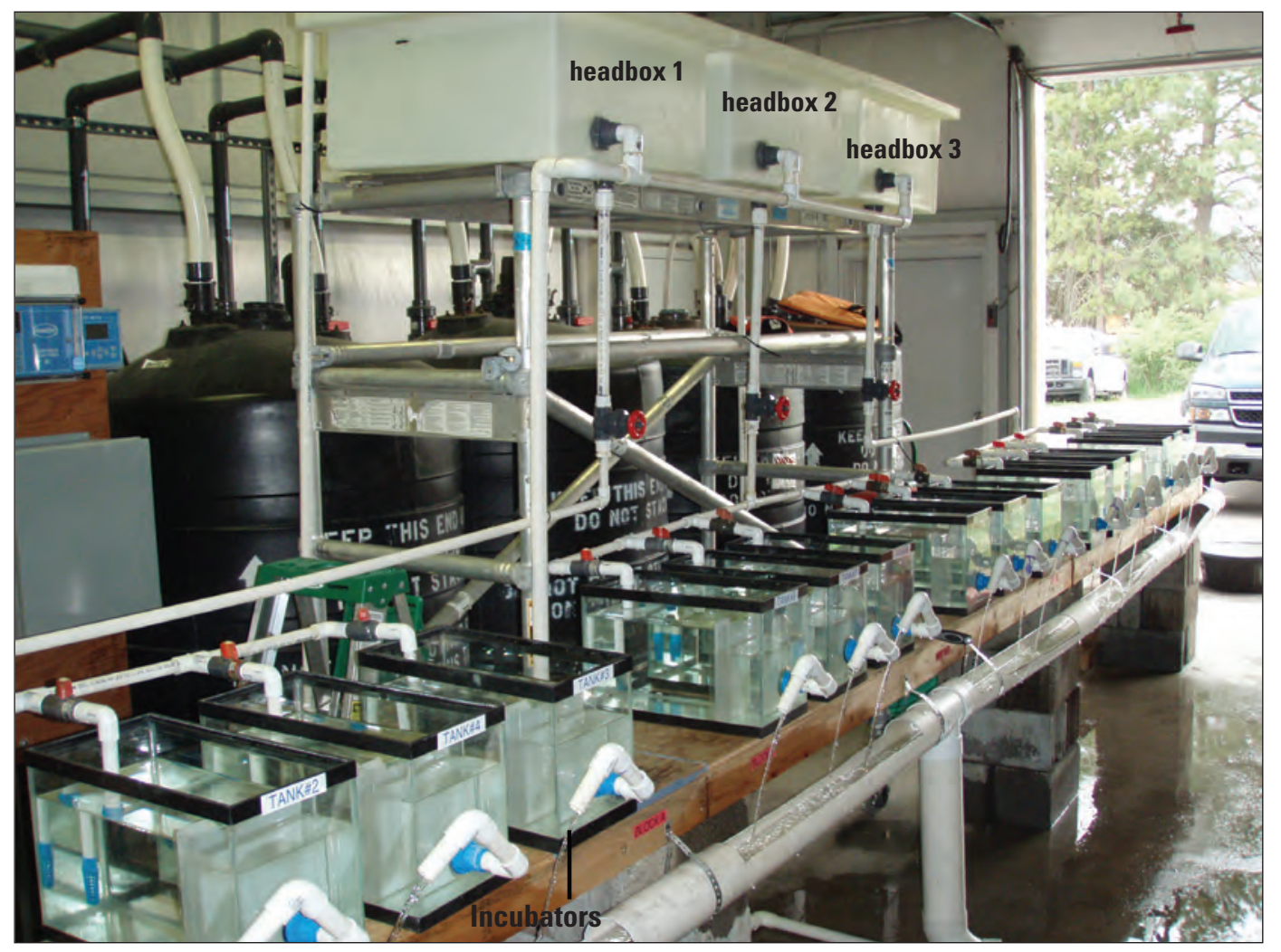

Figure 1. Arrangement of incubators in the $6 \times 3$ block design. The three headboxes supplied water to the incubators. Headboxes received water that contained a mix of unheated and heated Kootenai River water. Photograph taken by Eric Kofoot, U.S. Geological Survey, 2007. 
water to the incubators was provided using three 113.4-L headboxes. The headboxes received water from a common line containing a mix of filtered heated and unheated Kootenai River water. Each headbox supplied water to a block of six incubators. Water temperatures in each of the three headboxes were recorded by autonomous temperature loggers $\left(\mathrm{HOBO}^{\circledR}\right.$ Water Pro, Onset Computer Corporation) each hour for the duration of the experiment. Water flow from the headbox to the individual incubators was regulated by gate valves. Water entered at the head of the incubator through 12.7-mm, polyvinyl chloride tubing with a 13-mm diameter diffuser placed near the bottom of the incubator. The distal end of the incubator was ported with a 1.9-cm-diameter, screen-covered bulkhead fitting for water outflow. Incubators were fitted with an 18.5-cm-high Cipoletti style overflow weir positioned $30 \mathrm{~cm}$ from the head of the incubator dividing the incubator into two chambers, the larger chamber held the substrates. The smaller chamber was designed to retain the free-swimming embryos when they passed over the weir. Equal flow of water through the incubators was achieved by monitoring water elevation through the notches in the overflow weirs.

\section{Incubation Substrates}

The periphyton- and algae-covered rocks used in the experiments were collected from near the mouth of Myrtle Creek (river kilometer [rkm] 234.0), a tributary to the Kootenai River. Rocks selected were relatively uniform in size and covered with moderate amounts of periphyton and algae growth (fig. 2). A single rock was used in an incubator.

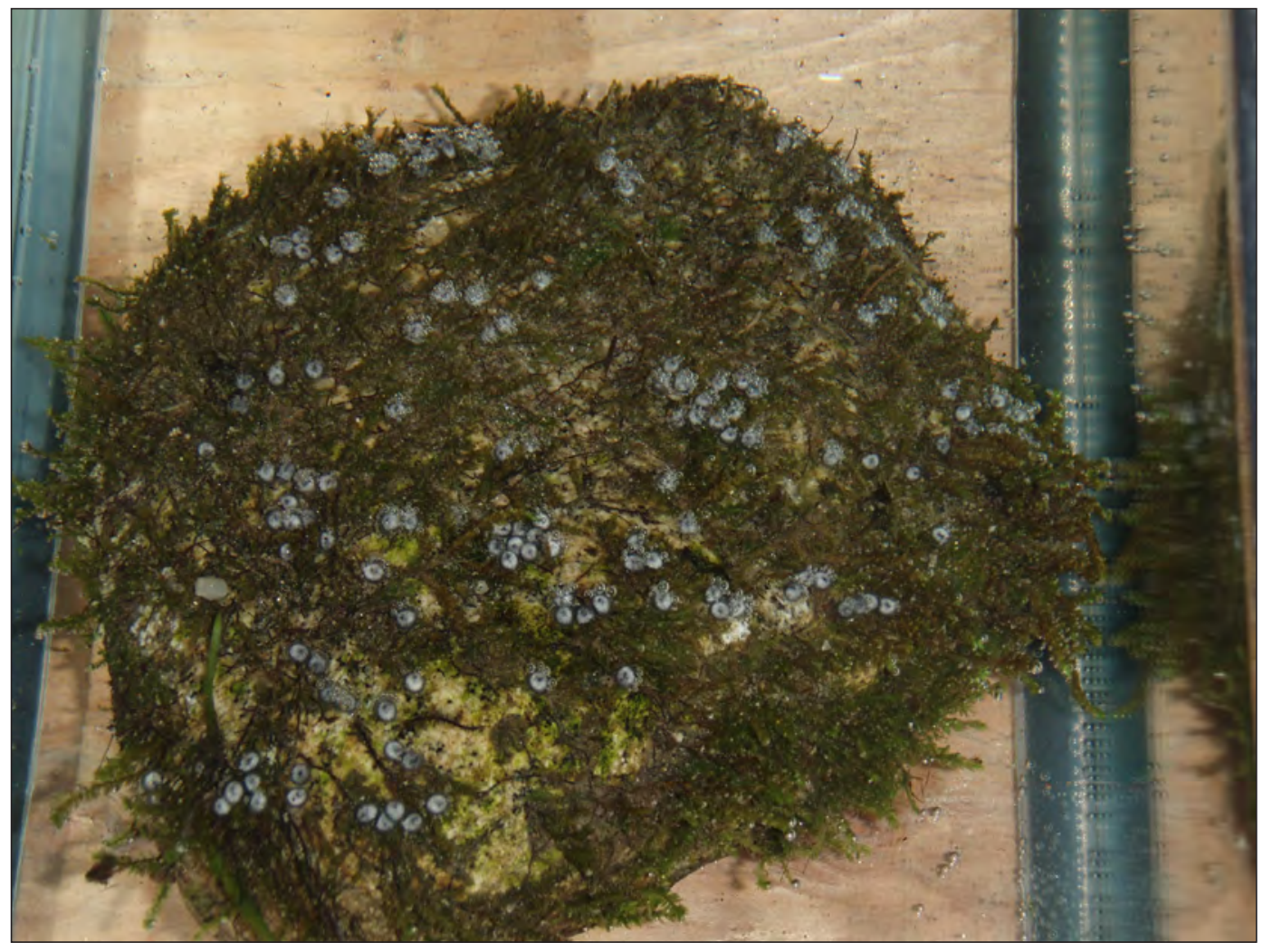

Figure 2. An incubator with developing embryos attached to a rock typical of a substrate covered with periphyton and algae. Photograph taken by Eric Kofoot, U.S. Geological Survey, 2007. 
The clean river rocks used were collected from the Moyie River (rkm 258.1), another tributary to the Kootenai River. These rocks were brushed and rinsed to remove any surface growth, and then allowed to dry in the sun prior to the start of the experiment. The clean river rocks were selected for uniform size, smoothness, and flatness to provide adequate surface area for egg attachment (fig. 3). Two clean rocks were used in an incubator.
Stems from four species of riparian vegetation were collected from along the banks of the Kootenai River-reed canarygrass (Phalaris arundinacea), Pacific willow (Salix lucida), black cottonwood (Populus trichocarpa), and redosier dogwood (Cornus sericea) (fig. 4). Three bunches of stems, containing equal numbers of stems from each of the four species, were created; one for each block.

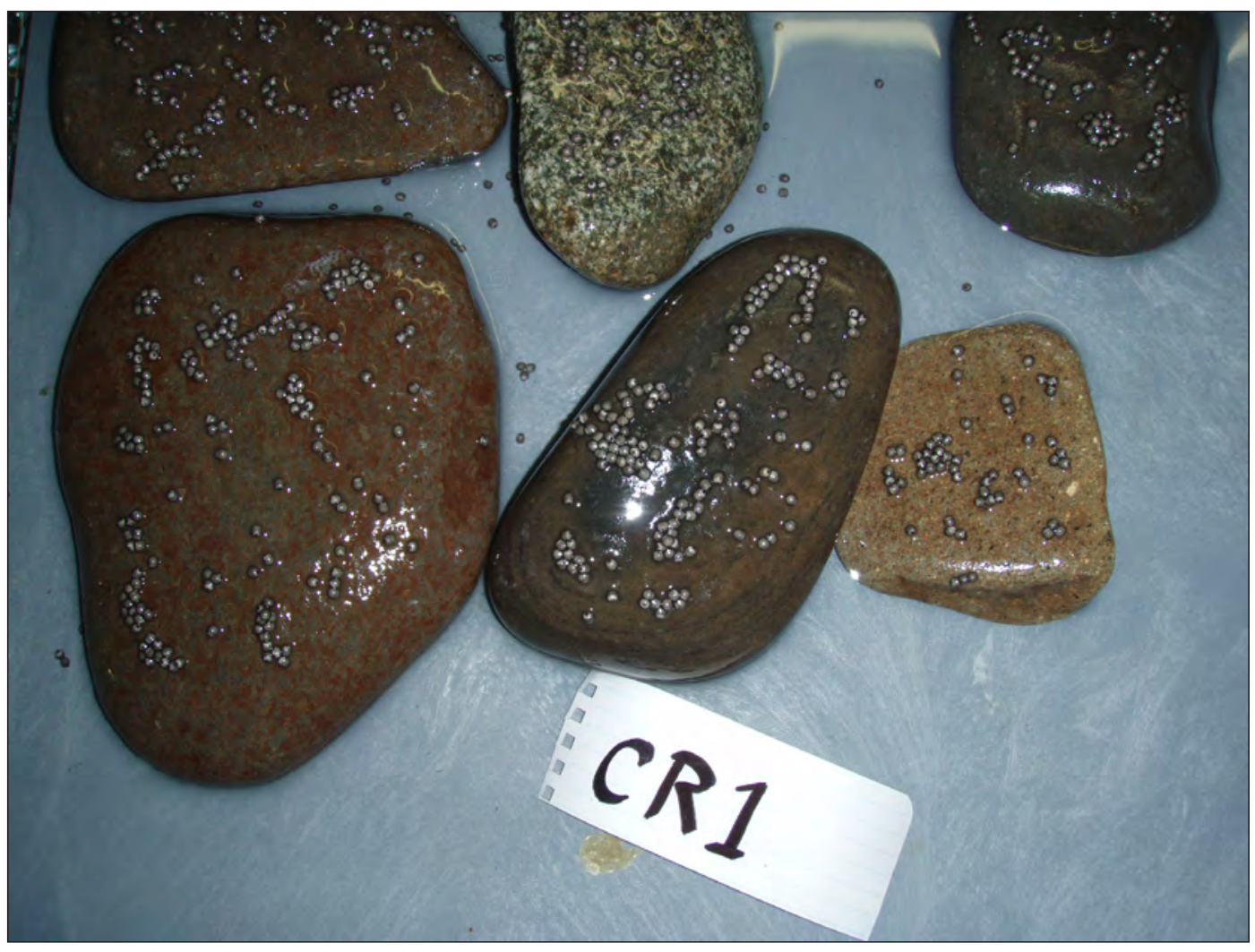

Figure 3. Developing embryos attached to clean river rocks typical of the substrate in many white sturgeon spawning areas. This photograph was taken shortly after the embryos were fertilized and before the clean river rocks were placed in the incubators. At that time, the substrates and embryos were under a misting system to keep them wet. Labels were used to ensure the proper placement of these substrates into a randomly selected incubator within a block (block 1 in this case). Photograph taken by Eric Kofoot, U.S. Geological Survey, 2007. 


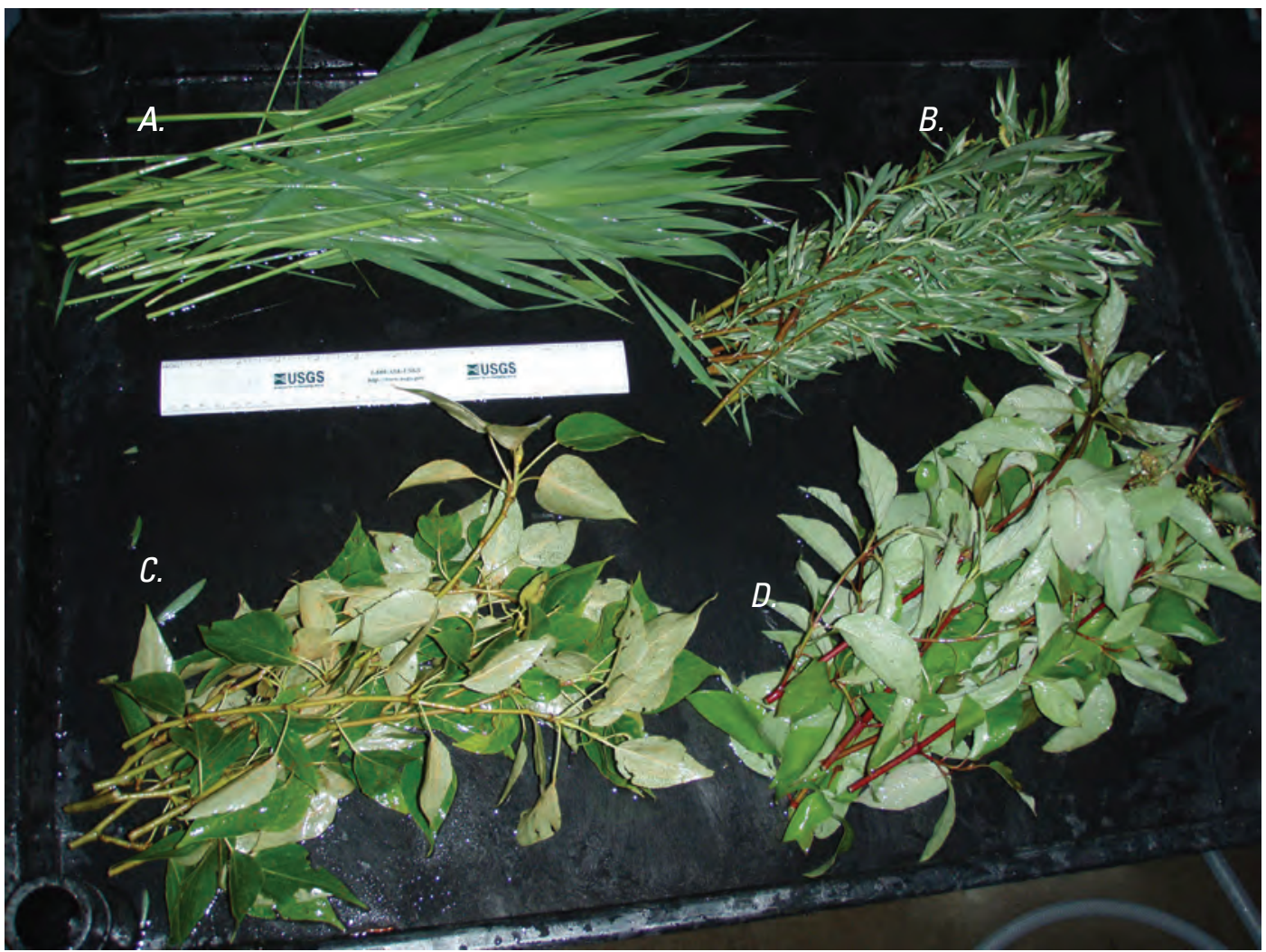

A 30.6-centimeter ruler provides a scale for reference.

Figure 4. Examples of the riparian vegetation used as substrates. A. Reed canarygrass (Phalaris arundinacea), B. Pacific willow (Salix lucida), C. Redosier dogwood (Cornus sericea), and D. Black cottonwood (Populus trichocarpa). Photograph taken by Eric Kofoot, U.S. Geological Survey, 2007.

The sand substrate was composed of a 2-cm layer of sifted general-purpose construction sand $(600 \mu \mathrm{m}-1 \mathrm{~mm}$ particle size) that covered the bottom of the incubator in each block.

Non-floating, waterlogged limbs from trees were collected from along the Kootenai River to serve as the waterlogged wood substrate. These limbs were about
$10.5 \mathrm{~cm}$ in diameter, and were cut into 25-cm lengths and split lengthwise to fit into the incubators. A single piece of waterlogged wood was used in an incubator.

Clean glass plates were cut from window-pane glass $(17.5 \times 26.5 \mathrm{~cm})$. A single plate was placed in horizontal orientation and supported $3 \mathrm{~cm}$ off the bottom of the incubator in each block. 


\section{Seeding the Incubation Substrates}

About 10,000 eggs were obtained from a single Kootenai River white sturgeon female on June 1, 2007, at 2000 hours. The eggs were placed in a 3.8-L stainless steel mixing bowl. The milt from two Kootenai River white sturgeon males was pooled and then mixed into $1,500 \mathrm{~mL}$ of water to activate the sperm. The activated sperm was then added to the eggs and gently stirred with a primary wing feather from a large bird for about 1 minute to allow fertilization to occur. Because of the rapidness of the onset of adhesion and the need to distribute the fertilized eggs (now embryos; Balon, 1975a), among 18 incubators, the embryos were then divided into three separate bowls and mixed for another 1-2 minutes until the jelly coat started to form and the eggs began to become adhesive. A subsample of embryos was then quickly collected with a common kitchen baster that then was used to gently distribute the embryos onto the individual substrates.

Because the embryos were quickly developing their adhesive envelopes, there was no time for a precise method to equalize the number of embryos placed onto substrates that were distributed among the 18 incubators. This resulted in variation in the number of embryos among incubators.
Substrates generally were seeded with embryos outside of the incubator and moved to the incubators after a 20-minute waiting period for adhesion to fully form. All substrates except for the riparian vegetation and sand were seeded with embryos under a commercial off-the-shelf patio misting system. Rock, wood, and glass substrates were wetted and placed in plastic trays $(80 \mathrm{~cm}$ long $\times 60 \mathrm{~cm}$ wide $\times 7 \mathrm{~cm}$ deep $)$ that were beneath the misting system. The misters kept the substrates and embryos moist during the initial stages of adhesion to the substrates. After 20 minutes had passed to allow embryos to fully adhere to the substrates, the individual substrates then were placed in the assigned incubator and water flow was initiated.

Each of the three riparian vegetation bunches was submersed in a separate 18.9-L bucket filled with water. The embryos then were distributed across the water surface and allowed to settle into the stems and leaves. After 30 minutes, each bunch with attached embryos was removed from the bucket and placed into the appropriate incubator.

The incubators containing sand had been previously filled with water to a depth of $7 \mathrm{~cm}$. The fertilized embryos were seeded over the water surface to settle onto the sand (fig. 5). Water flow was initiated after 30 minutes.

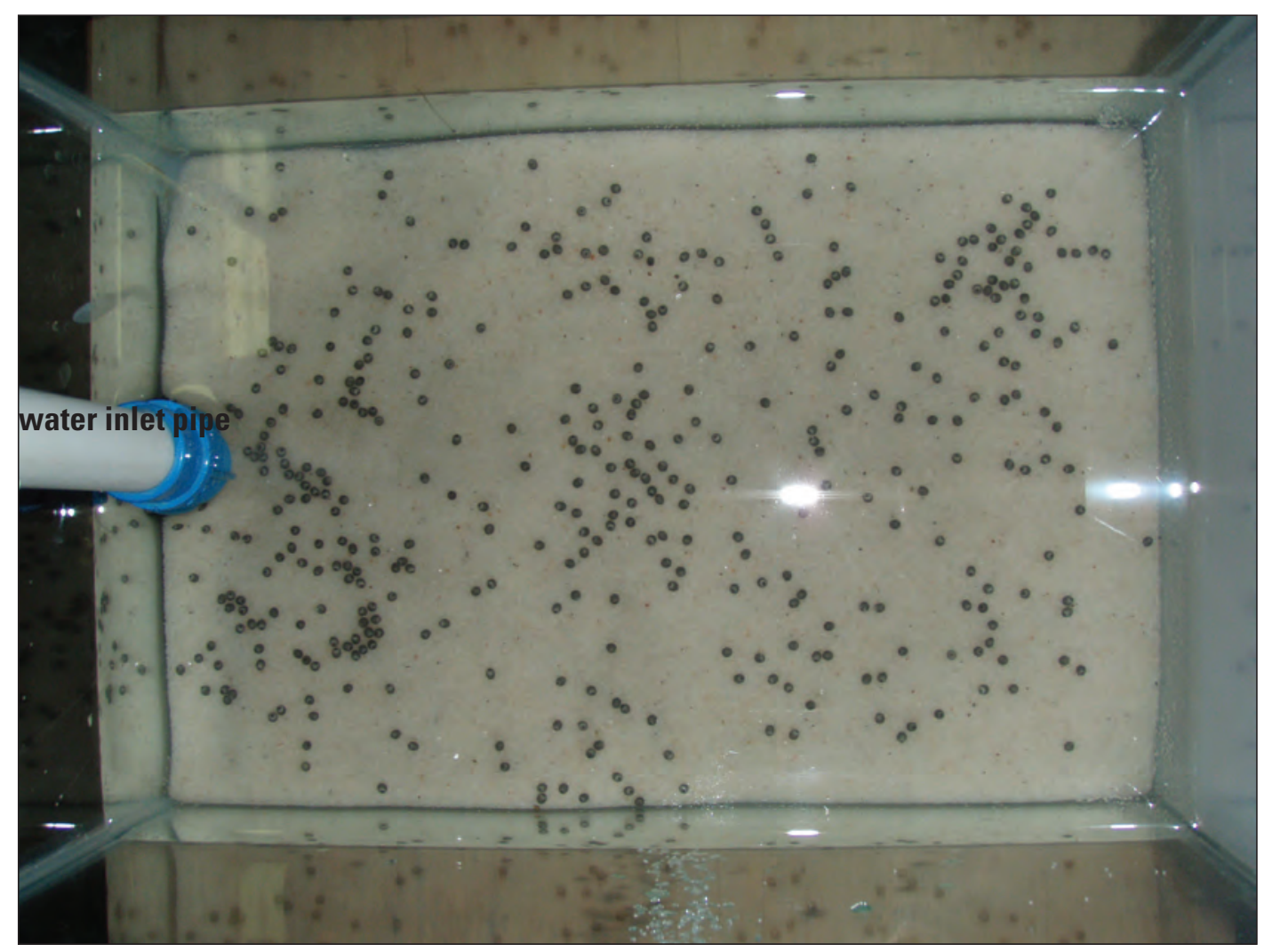

Figure 5. An incubator with white sturgeon embryos on a sand substrate. Embryos had just been placed in the incubator and the water was not flowing. Photograph taken by Eric Kofoot, U.S. Geological Survey, 2007. 


\section{Incubation, Hatch, and Analysis of Data}

A visual inspection of the incubators was made each morning and evening and periodically throughout the day. Free-swimming embryos were removed from the incubators immediately after being observed. The time (in minutes) was noted and total lengths were measured (to the nearest $0.01 \mathrm{~mm}$ ) under an illuminated magnifying lamp with a digital caliper (Mitutoyo model CD-6-CS). Damaged or deformed embryos were enumerated but not measured to provide a total number of hatched embryos from each incubator.

The experiment was terminated between 1900 and 2100 hours on June 12, 2007. At that time, all unhatched embryos and the substrates that they were attached to were removed from the incubators and preserved in 10-percent buffered formalin. In the laboratory, the preserved embryos were rinsed, separated from the substrate materials, and transferred to 70-percent ethanol. The unhatched embryos then were counted under a dissecting microscope. Clusters of embryos that were bound together by fungus were gently separated to determine how many embryos were in the cluster. The total number of unhatched embryos remaining in each incubator was determined from counts made by two individuals. When counts differed, additional counts were made until a consensus was reached.

The water temperature data loggers were downloaded and review of the hourly temperature s revealed some variation in water temperature during the experiment but no difference in water temperature among the headboxes (fig. 6). A drop in water temperature of approximately $2.5^{\circ} \mathrm{C}$ within the experiment occurred on June 5 when the hatchery facility demands for heated water reduced heated water supply to our experiment.

Several metrics were used to evaluate the effects of substrate type on incubation of white sturgeon embryosthe proportion of hatched embryos, incubation time to first hatch, incubation time to 50-percent hatch, and total length of free-swimming embryos. The initial number of embryos that were placed into each incubator was determined by adding the number of hatched free-swimming embryos to the number of unhatched embryos counted in the laboratory. The effect of substrate type on these metrics was assessed using a two-way analysis of variance.

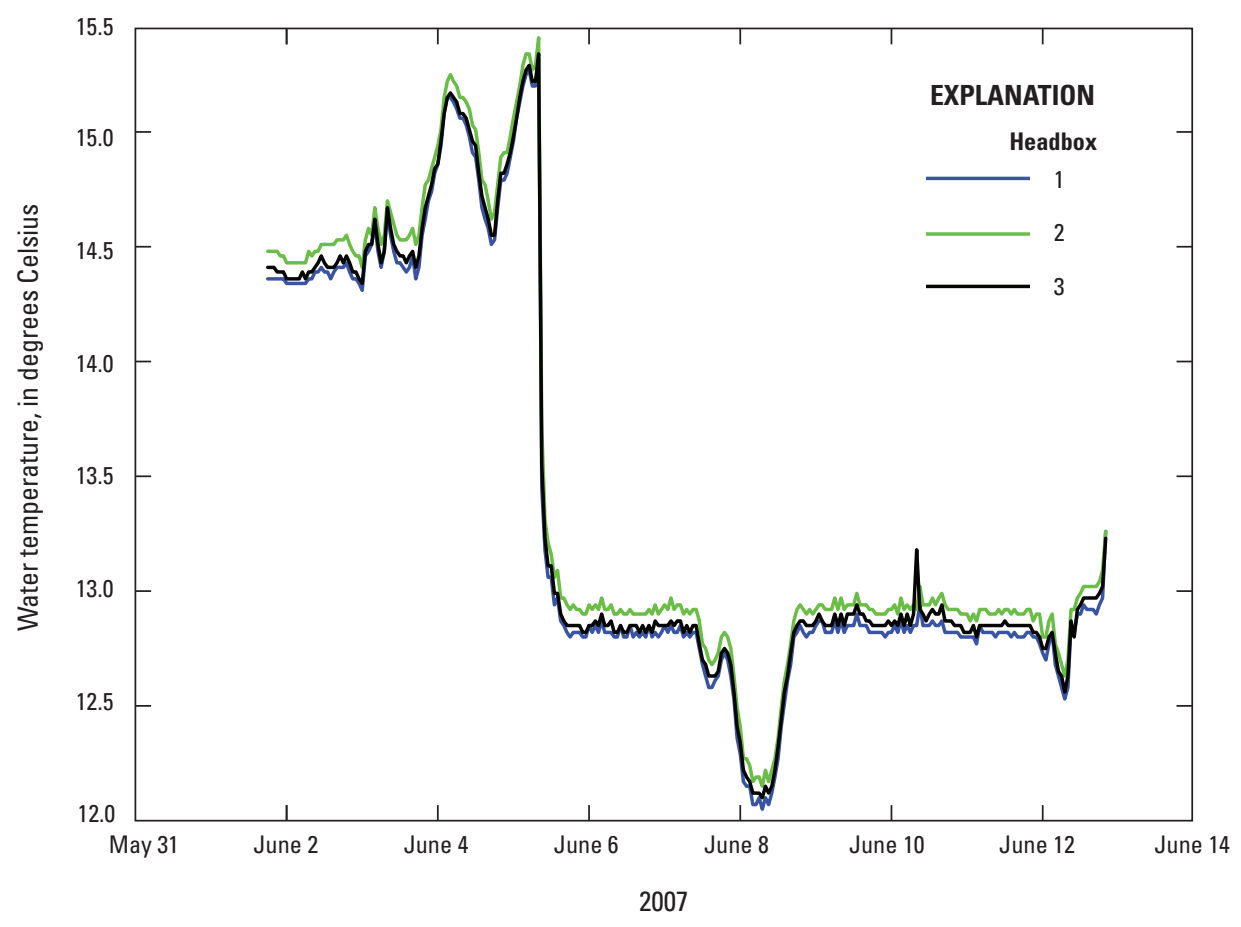

Figure 6. Water temperatures recorded hourly in the three headboxes that supplied water to the incubation tanks. The graph shows that water temperature varied over time but there was little difference among headboxes that supplied the incubation chambers. The decrease in temperature on June 5 was caused by a decrease in hot water delivered to this experiment because of the need for additional hot water in the Kootenai Tribal Sturgeon Hatchery. 


\section{Effect of Substrate on Hatch Timing and Success}

All substrates with embryos attached had been placed into the incubators by 2200 hours on June 1, 2007. Approximately 9 hours later, many bubbles had formed on surfaces throughout the incubators and on many of the embryos. Bubbles that had formed on the embryos on the sand substrates had increased the buoyancy of the embryos enough to lift them from the substrate. Most of the embryos had floated to the surface and were aggregated at the notch in the water-level control weir (fig. 7). Given that the embryos on the sand substrate in all three incubators were no longer attached to the sand, the decision was made to exclude this substrate type from further analysis. All incubators then were inspected and, despite the presence of bubbles in all incubators, no embryos had detached from the other substrates.

Hatch timing and success was first observed in an incubator with a clean river rock substrate at 0905 hours on June 9, 2007, approximately 7.5 days (179.1 hours) after the eggs were fertilized (hours to first hatch; table 1). Hatch began in six other incubators within hours. Hatch was first observed in six more incubators the following day, and hatch was observed in the last two incubators on June 11. Substrate had an effect on incubation time to first hatch at $\alpha=0.1$ but not at $\alpha=0.05$ (table 2). A multiple comparison test (Tukey HSD) showed that incubation time to first hatch was shorter on clean river rock substrate than on periphyton- and algae-covered rock substrate and waterlogged wood substrate (table 3).

Substrate also influenced incubation time to 50-percent hatch at $\alpha=0.001$ (table 4) and the multiple comparison test revealed significant differences between most substrates (table 5).

Hatch success varied among incubation substrates and between blocks for each substrate type (table 1). Hatch success ranged from a low of 2.7 percent in an incubator with a periphyton- and algae-covered rock substrate, to a

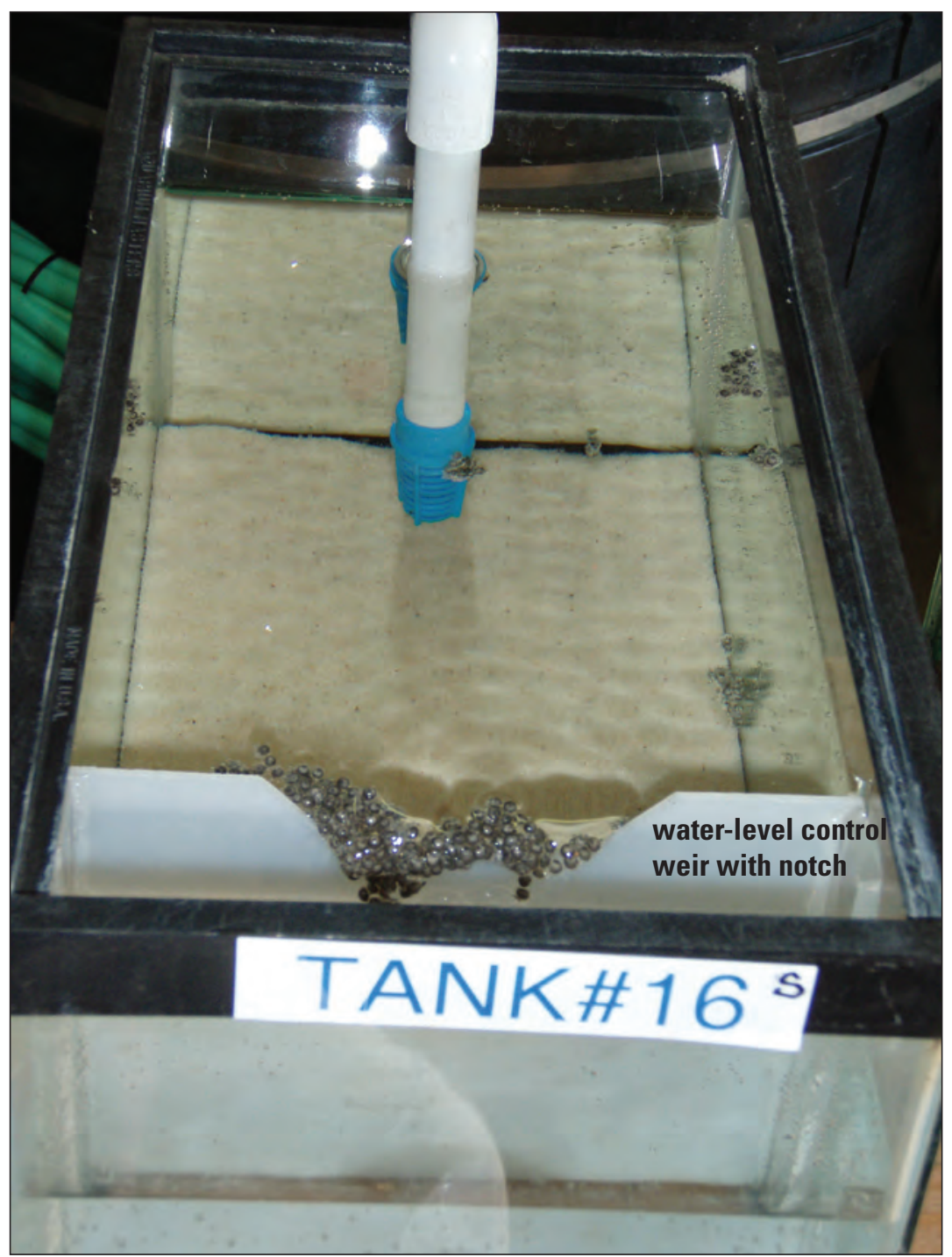

Figure 7. An incubator with sturgeon embryos that had floated off the sand substrate and become lodged in the notch of the water-level control weir. Other clusters of embryos can be seen floating at the water surface. The water inlet pipe with diffuser is in the back of the chamber. Photograph by Eric Kofoot, U.S. Geological Survey, 2007.

high of 60.7 percent in an incubator with a clean glass plate substrate. Substrate had a significant effect on incubation success (table 6), and the multiple comparison test showed that differences in mean proportion of embryos that hatched were lowest for embryos attached to the periphyton- and algae-covered rock substrate (table 7). 
Table 1. Incubation and hatch data associated with each incubator.

[Eggs were fertilized at 2000 hours on June 1, 2007. Abbreviation: mm, millimeter]

\begin{tabular}{|c|c|c|c|c|c|c|c|c|c|c|}
\hline \multirow{2}{*}{$\begin{array}{l}\text { Substrate type } \\
\text { Clean river rocks }\end{array}$} & \multicolumn{2}{|c|}{$\begin{array}{c}\text { Incubator } \\
\text { No. } \\
\text { (block) }\end{array}$} & \multirow{2}{*}{$\begin{array}{c}\begin{array}{c}\text { Number of } \\
\text { embryos in } \\
\text { incubator }\end{array} \\
167\end{array}$} & \multicolumn{2}{|c|}{$\begin{array}{c}\text { Date and time } \\
\text { hatch was } \\
\text { first noted }\end{array}$} & \multirow{2}{*}{$\begin{array}{c}\begin{array}{c}\text { Hours to } \\
\text { first hatch }\end{array} \\
184.5\end{array}$} & \multirow{2}{*}{$\begin{array}{c}\begin{array}{c}\text { Hours to } \\
\mathbf{5 0} \text { percent } \\
\text { hatch }\end{array} \\
228.2 \\
\end{array}$} & \multirow{2}{*}{\begin{tabular}{|c|}
$\begin{array}{c}\text { Total } \\
\text { length } \\
\text { (mm) }\end{array}$ \\
11.66 \\
\end{tabular}} & \multirow{2}{*}{$\begin{array}{c}\begin{array}{c}\text { Number of } \\
\text { embryos } \\
\text { hatched }\end{array} \\
62 \\
\end{array}$} & \multirow{2}{*}{$\begin{array}{c}\begin{array}{c}\text { Percentage } \\
\text { of hatch }\end{array} \\
37.1\end{array}$} \\
\hline & 1 & $(1)$ & & June 9 & $17: 00$ & & & & & \\
\hline & 13 & (3) & 176 & June 9 & $12: 30$ & 181.1 & 208.0 & 11.37 & 39 & 22.2 \\
\hline Periphyton- and algae-covered rocks & 3 & $(1)$ & 134 & June 11 & $07: 50$ & 227.8 & 228.8 & 11.64 & 11 & 8.2 \\
\hline \multirow[t]{3}{*}{ Waterlogged wood } & 6 & $(1)$ & 104 & June 10 & 08:05 & 204.1 & 253.0 & 12.04 & 20 & 19.2 \\
\hline & 12 & $(2)$ & 141 & June 10 & $10: 10$ & 206.2 & 236.8 & 11.76 & 80 & 56.7 \\
\hline & 18 & (3) & 197 & June 11 & $11: 37$ & 231.6 & 259.4 & 11.61 & 38 & 19.3 \\
\hline Sand & 4 & (1) & 304 & - & & - & - & - & - & - \\
\hline Riparian vegetation & 17 & (3) & 198 & June 10 & $11: 00$ & 207.0 & 237.8 & 11.89 & 49 & 24.8 \\
\hline \multirow[t]{3}{*}{ Clean glass plates } & 2 & (1) & 120 & June 9 & $16: 45$ & 188.8 & 254.0 & 12.33 & 57 & 47.5 \\
\hline & 8 & (2) & 272 & June 10 & 09:45 & 205.8 & 235.9 & 12.13 & 165 & 60.7 \\
\hline & 14 & (3) & 108 & June 9 & $16: 55$ & 188.9 & 231.8 & 11.72 & 34 & 31.5 \\
\hline
\end{tabular}

Table 2. Two-way analysis of variance results for incubation substrate effects on incubation time to first hatch.

[Response: Incubation time to incubation time to first hatch]

\begin{tabular}{lcrccc}
\hline & Df & Sum sq & Mean sq & F value & $\operatorname{Pr}(>\mathbf{F})$ \\
\hline Substrate & 4 & $2,063.72$ & 515.93 & 3.6656 & 0.05572 \\
Group & 2 & 71.55 & 35.77 & 0.2542 & 0.78159 \\
Residuals & 8 & $1,126.00$ & 140.75 & & \\
\hline
\end{tabular}

Table 3. Tukey multiple comparisons of means of time to first hatch for each substrate.

[Difference is the difference between the means of time for each substrate pair comparison. Lower and Upper are the confidence intervals. $\mathrm{p}$ adjusted is the test statistic]

\begin{tabular}{lrrcc}
\hline \multirow{2}{*}{\multicolumn{1}{c}{ Substrate }} & \multicolumn{3}{c}{ Tukey multiple comparison test results } \\
\cline { 2 - 5 } & Difference & Lower & Upper & p adjusted \\
\hline Clean glass plates - Clean river rock & 10.6667 & 17.8860 & 39.2194 & 0.8018 \\
Periphyton- and algae-covered rock - Clean river rock & 29.5333 & 0.9806 & 58.0860 & 0.0871 \\
Riparian vegetation - Clean river rock & 11.4000 & 17.1527 & 39.9527 & 0.7640 \\
Waterlogged wood - Clean river rock & 30.1333 & 1.5806 & 58.6860 & 0.0800 \\
Periphyton- and algae-covered rock - Clean glass plates & 18.8667 & -9.6860 & 47.4194 & 0.3670 \\
Riparian vegetation - Clean glass plates & 0.7333 & 27.8194 & 29.2860 & 1.0000 \\
Waterlogged wood - Clean glass plates & 19.4667 & -9.0860 & 48.0194 & 0.3410 \\
Riparian vegetation - Periphyton- and algae-covered rock & -18.1333 & 46.6860 & 10.4194 & 0.4005 \\
Waterlogged wood - Periphyton- and algae-covered rock & 0.6000 & 27.9527 & 29.1527 & 1.0000 \\
Waterlogged wood - Riparian vegetation & 18.7333 & -9.8194 & 47.2860 & 0.3729 \\
\hline
\end{tabular}


Table 4. Two-way analysis of variance results for incubation substrate effects on incubation time to achieve 50-percent hatch.

[Response: Incubation time to 50-percent hatch]

\begin{tabular}{lcrrrr}
\hline & Df & Sum sq & Mean sq & F value & $\operatorname{Pr}(>\mathbf{F})$ \\
\hline Substrate & 4 & $2,710.51$ & 677.63 & 15.7512 & 0.0007 \\
Group & 2 & 735.63 & 367.81 & 8.5497 & 0.0103 \\
Residuals & 8 & 344.17 & 43.02 & & \\
\hline
\end{tabular}

Table 5. Tukey multiple comparisons of means of time to achieve 50-percent hatch from each substrate.

[Difference is the difference between the means of time for each substrate pair comparison. Lower and Upper are the confidence intervals. $\mathrm{p}$ adjusted is the test statistic]

\begin{tabular}{lrrrc}
\hline \multirow{2}{*}{\multicolumn{1}{c}{ Substrate }} & \multicolumn{3}{c}{ Tukey multiple comparison test results } \\
\cline { 2 - 5 } & Difference & Lower & Upper & p adjusted \\
\hline Clean glass plates-Clean river rock & 24.1000 & 8.2175 & 39.9825 & 0.0131 \\
Periphyton- and algae-covered rock - Clean river rock & 3.0000 & -12.8825 & 18.8825 & 0.9779 \\
Riparian vegetation-Clean river rock & 26.2667 & 10.3841 & 42.1492 & 0.0079 \\
Waterlogged wood-Clean river rock & 33.2667 & 17.3841 & 49.1492 & 0.0018 \\
Periphyton- and algae-covered rock-Clean glass plates & -21.1000 & -36.9825 & -5.2175 & 0.0269 \\
Riparian vegetation-Clean glass plates & 2.1667 & 13.7159 & 18.0492 & 0.9934 \\
Waterlogged wood-Clean glass plates & 9.1667 & -6.7159 & 25.0492 & 0.4829 \\
Riparian vegetation-Periphyton- and algae-covered rock & 23.2667 & 7.3841 & 39.1492 & 0.0159 \\
Waterlogged wood-Periphyton- and algae-covered rock & 30.2667 & 14.3841 & 46.1492 & 0.0033 \\
Waterlogged wood-Riparian vegetation & 7.0000 & -8.8825 & 22.8825 & 0.6993 \\
\hline
\end{tabular}


Table 6. Two-way analysis of variance results for incubation substrate effects on proportion of hatched embryos.

[Response: Proportion of hatched embryos]

\begin{tabular}{lcrccr}
\hline & Df & Sum sq & Mean sq & F value & $\operatorname{Pr}(>\mathbf{F})$ \\
\hline Substrate & 4 & $2,118.54$ & 529.63 & 5.2690 & 0.02235 \\
Group & 2 & $1,091.70$ & 545.85 & 5.4303 & 0.03237 \\
Residuals & 8 & 804.16 & 100.53 & & \\
\hline
\end{tabular}

Table 7. Tukey multiple comparisons of means of the proportion of hatched embryos from each substrate.

[Difference is the difference between the means of time for each substrate pair comparison. Lower and Upper are the confidence intervals. p adjusted is the test statistic]

\begin{tabular}{lrrrc}
\hline \multirow{2}{*}{\multicolumn{1}{c}{ Substrate }} & \multicolumn{3}{c}{ Tukey multiple comparison test results } \\
\cline { 2 - 5 } & Difference & Lower & Upper & p adjusted \\
\hline Clean glass plates - Clean river rock & 18.3333 & -5.7961 & 42.4628 & 0.2567 \\
Periphyton- and algae-covered rock - Clean river rock & -18.9667 & -43.0962 & 5.1628 & 0.2325 \\
Riparian vegetation - Clean river rock & 0.3000 & -23.8295 & 24.4295 & 1.0000 \\
Waterlogged wood - Clean river rock & 3.5000 & -20.6295 & 27.6295 & 0.9917 \\
Periphyton- and algae-covered rock - Clean glass plates & -37.3000 & -61.4295 & -13.1705 & 0.0117 \\
Riparian vegetation - Clean glass plates & -18.0333 & -42.1628 & 6.0962 & 0.2689 \\
Waterlogged wood - Clean glass plates & -14.8333 & -38.9628 & 9.2962 & 0.4284 \\
Riparian vegetation - Periphyton- and algae-covered rock & 19.2667 & -4.8628 & 43.3962 & 0.2218 \\
Waterlogged wood - Periphyton- and algae-covered rock & 22.4667 & -1.6628 & 46.5962 & 0.1319 \\
Waterlogged wood - Riparian vegetation & 3.2000 & -20.9295 & 27.3295 & 0.9940 \\
\hline
\end{tabular}




\section{Effect of Substrate on Free-Embryo Length at Hatch}

Total lengths were obtained from 612 newly hatched embryos (table 8). Total lengths ranged from 8.81 to $13.44 \mathrm{~mm}$ (fig. 8) and incubation substrate had an effect on total length at hatch at $\alpha=0.1$ but not at $\alpha=0.05$ (table 9). The multiple comparison test failed to identify a significant difference $(\alpha=0.1)$ in total length at hatch between any two incubation substrates (table 10) perhaps because of the small number of free-swimming embryos available to measure from the incubators containing the periphyton- and algae-covered rock substrate.

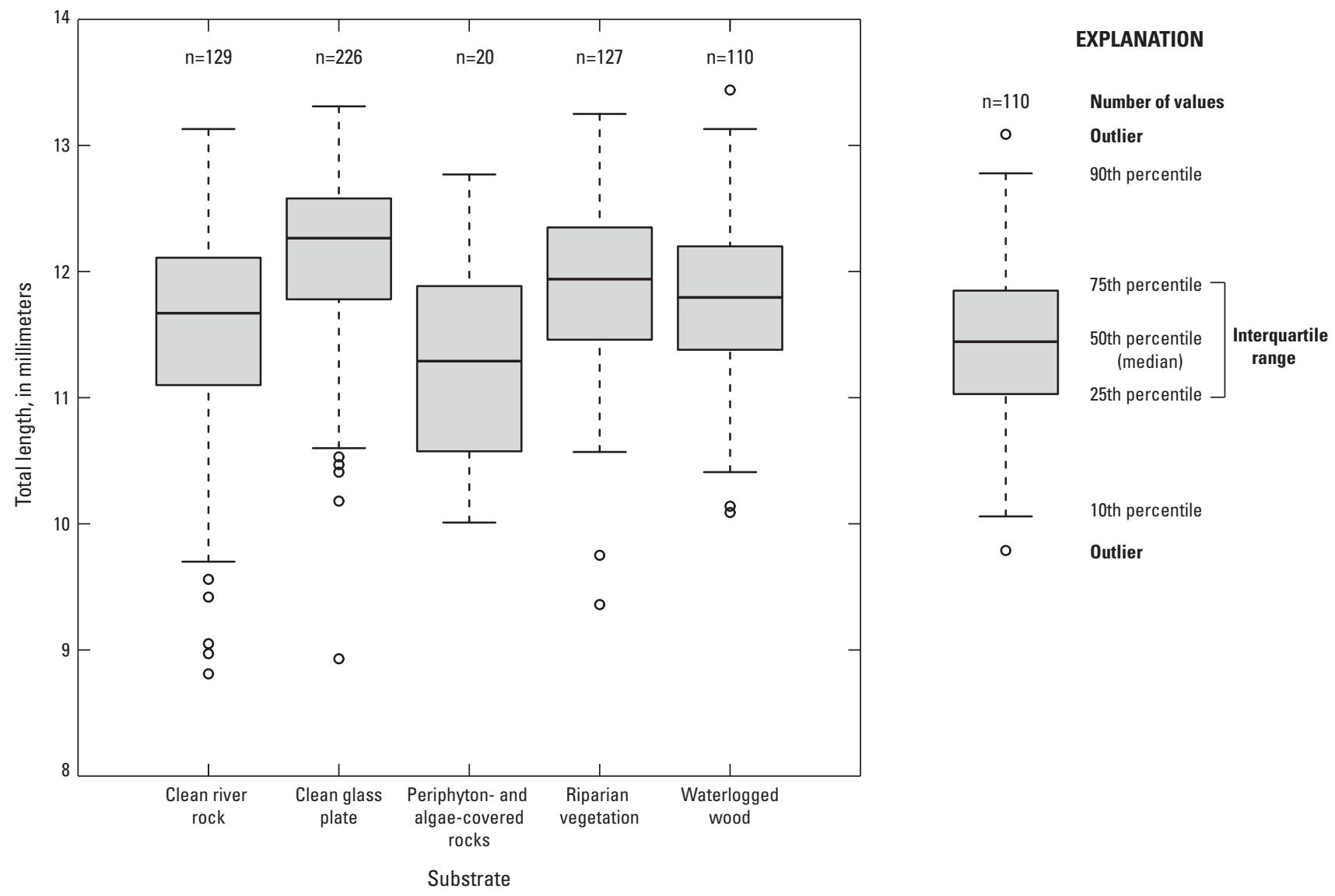

Figure 8. Total lengths of free-swimming hatched embryos from different incubation substrates. 
Table 8. Number of free-swimming embryos measured for total length from each incubation substrate.

\begin{tabular}{cccccc}
\hline & \multicolumn{4}{c}{ Number of free-swimming embyros measured for total length } \\
\cline { 2 - 6 } Block & $\begin{array}{c}\text { Clean river } \\
\text { rock }\end{array}$ & $\begin{array}{c}\text { Periphyton- and } \\
\text { algae-covered } \\
\text { rock }\end{array}$ & $\begin{array}{c}\text { Waterlogged } \\
\text { wood }\end{array}$ & $\begin{array}{c}\text { Riparian } \\
\text { vegetation }\end{array}$ & $\begin{array}{c}\text { Clean glass } \\
\text { plates }\end{array}$ \\
\hline 1 & 53 & 4 & 19 & 40 & 45 \\
2 & 39 & 13 & 76 & 60 & 156 \\
3 & 37 & 3 & 15 & 27 & 25 \\
Totals & 129 & 20 & 110 & 127 & 226 \\
\hline
\end{tabular}

Table 9. Two-way analysis of variance results for incubation substrate effects on total length of free-swimming hatched embryos.

[Response: Total length of free-swimming embryos]

\begin{tabular}{lccccc}
\hline & Df & Sum sq & Mean sq & F value & $\operatorname{Pr}(>\mathbf{F})$ \\
\hline Substrate & 4 & 0.66233 & 0.165582 & 3.0002 & 0.08703 \\
Group & 2 & 0.18751 & 0.093756 & 1.6988 & 0.24273 \\
Residuals & 8 & 0.44152 & 0.055190 & & \\
\hline
\end{tabular}

Table 10. Tukey multiple comparisons of means of total lengths of newly hatched embryos from each substrate.

[Difference is the difference between the means of time for each substrate pair comparison. Lower and Upper are the confidence intervals. $\mathrm{p}$ adjusted is the test statistic]

\begin{tabular}{lcccc}
\hline \multirow{2}{*}{\multicolumn{1}{c}{ Substrate }} & \multicolumn{3}{c}{ Tukey multiple comparison test results } \\
\cline { 2 - 5 } & Difference & Lower & Upper & p adjusted \\
\hline Clean glass plates - Clean river rock & 0.5039 & -0.1588 & 1.1665 & 0.1545 \\
Periphyton- and algae-covered rock - Clean river rock & -0.0459 & -0.7086 & 0.6168 & 0.9991 \\
Riparian vegetation - Clean river rock & 0.3635 & -0.2992 & 1.0262 & 0.3901 \\
Waterlogged wood - Clean river rock & 0.2467 & -0.4160 & 0.9094 & 0.7063 \\
Periphyton- and algae-covered rock - Clean glass plates & -0.5497 & -1.2124 & 0.1129 & 0.1118 \\
Riparian vegetation - Clean glass plates & -0.1404 & -0.8030 & 0.5223 & 0.9429 \\
Waterlogged wood - Clean glass plates & -0.2572 & -0.9198 & 0.4055 & 0.6768 \\
Riparian vegetation - Periphyton- and algae-covered rock & 0.4094 & -0.2533 & 1.0721 & 0.2930 \\
Waterlogged wood - Periphyton- and algae-covered rock & 0.2926 & -0.3701 & 0.9553 & 0.5756 \\
Waterlogged wood - Riparian vegetation & -0.1168 & -0.7795 & 0.5459 & 0.9696 \\
\hline
\end{tabular}




\section{Summary}

Benthic fish embryos are exposed to numerous environmental hazards (Peterka and Kent, 1976). These hazards are a major ecological factor determining the reproductive success in fishes (Balon, 1975b, 1984), including sturgeons. Incubation substrates that result in the earliest hatch and greatest overall hatch success have the greatest potential to sustain populations. This study showed that clean river rocks generally were more suitable than other tested substrates expected to be found in the Kootenai River. However, other substrates, such as waterlogged wood and riparian vegetation also performed well. Sand, which currently (2013) dominates the riverbed in some known spawning areas in the highly altered Kootenai River, was unsuitable as a substrate for adhesive eggs because the developing embryos were easily mobilized from the substrate. In these experiments, the formation of small air bubbles showed the ease with which embryos deposited on sands could be dislodged. Water currents in rivers, even at the low velocities typical of some Kootenai River spawning areas, would likely mobilize eggs that were deposited on sands. It was beyond the scope of this study to determine the fate of dislodged embryos.

Incubating white sturgeon embryos are susceptible to death from suffocation by sediment cover (Kock and others, 2006), predation (Miller and Beckman, 1996), and parasitism by spreading aquatic fungi (Scott and O'Bier, 1962; Conte and others, 1988). Fungus growth on developing embryos can quickly spread to adjacent embryos and cause high mortality. Although fungal infection was not quantified in these experiments, fungus growth was more prevalent on the periphyton- and algae-covered rocks than on other substrates, and was believed to be the primary cause of the reduced hatch success of embryos seeded on this substrate. Operation of Kootenai River dams for flood risk management and hydropower benefits during the white sturgeon spawning season have largely eliminated spring scouring flows that typically clean rocks of overlying growth.

This laboratory study suggests that several substrate types may be suitable for spawning habitat restoration-clean river rock, waterlogged wood, and riparian vegetation. Waterlogged wood is present in the Kootenai River and may currently (2013) be serving as an embryo incubation substrate in some known spawning sites of white sturgeon. The inclusion of waterlogged wood in Kootenai River sturgeon spawning habitat restoration efforts in areas dominated by sand or periphyton- and algae-covered rocks could improve incubation success. Coutant (2004) suggested that submerged aquatic and riparian vegetation may serve as important incubation sites for white sturgeon embryos; however, white sturgeon embryos have not yet been observed incubating on stems and leaves of vegetation, although few field studies have looked specifically for white sturgeon embryos in shallow riparian habitats (van der Leeuw and others, 2006). Field studies that have collected incubating white sturgeon embryos in other river systems reported that catches were greatest over rocks (Parsley and others, 1993; McCabe and Tracy, 1994; Schaffter, 1997; Perrin and others, 2003) and gravels (Schaffter, 1997). However, it is apparent from this study that substrates for adhesion and incubation of white sturgeon embryos must remain relatively clean to reduce the spread of embryo-killing fungus. Achieving clean substrates may require restoration strategies that maximize scouring flows prior to or during the spawning period for white sturgeon.

\section{Acknowledgments}

The Kootenai Tribe of Idaho graciously allowed us to use their sturgeon hatchery facility to conduct the experiments. Kootenai Tribal Sturgeon Hatchery staff-including John (Jack) Siple, Eric Wagner, and Chris Lewandowski-captured the brood stock and spawned the eggs that were used in this experiment. Bjorn van der Leeuw and Tim Blubaugh of the U.S. Geological Survey assisted with the experiment and with data entry. Funding for this project was provided by the Bonneville Power Administration through the Kootenai Tribe of Idaho.

\section{References Cited}

Anders, P.A., Richards, D.L., and Powell, M.S., 2002, The first endangered white sturgeon population-Repercussions in an altered large river-floodplain ecosystem, in Van Winkle, W., Anders, P.A., Secor, D.H., and Dixon, D.A., eds., Biology and management of North American Sturgeon: American Fisheries Society Symposium 28, Bethesda, Maryland, p. 67-82.

Balon, E.K., 1975a, Terminology of intervals in fish development: Journal of the Fisheries Research Board of Canada, v. 32, no. 9, p. 1663-1670.

Balon, E.K., 1975b, Reproductive guilds of fishes-A proposal and definition: Journal of the Fisheries Research Board of Canada, v. 32, no. 9, p. 821-864.

Balon, E.K., 1984, Reflections on some decisive events in the early life of fishes: Transactions of the American Fisheries Society, v. 113, no. 2, p. 178-185. 
Barton, G.J., 2003, Characterization of channel substrate, and changes in suspended-sediment transport and channel geometry in white sturgeon spawning habitat in the Kootenai River near Bonners Ferry, Idaho, following closure of Libby Dam: U.S. Geological Survey Water-Resources Investigations Report 03-4324, 102 p. (Also available at http://pubs.er.usgs.gov/publication/ wri034324.)

Beamesderfer, R., Justice, C., Neufeld, M., Rust, P., Paragamian, V., and Ireland, S., 2009, Kootenai sturgeon population status update: Report prepared for the Bonneville Power Administration by the Kootenai Tribe of Idaho, 41 p., accessed August 12, 2013, at http://www. restoringthekootenai.org/resources/F\&W-Library/Sturgeon/ Beamesderfer2009KootenaiSturgeonStatusupdate.pdf.

Conte, F.C., Doroshov, S.I., Lutes, P.B., and Strange, E.M., 1988, Hatchery manual for the white sturgeon Acipenser transmontanus Richardson, with application to other North American Acipenseridae: Oakland, California, Cooperative Extension, University of California, Division of Agriculture and Natural Resources, Publication 3322.

Coutant, C.C., 2004, A riparian habitat hypothesis for successful reproduction of white sturgeon: Reviews in Fisheries Science, v. 12, no. 1, p. 23-73.

Deng, X., Van Eenennaam, J.P., and Doroshov, S.I., 2002, Comparison of early life stages and growth of green and white sturgeon, in Van Winkle, W., Anders, P.A., Secor, D.H., and Dixon, D.A., eds., Biology and management of North American Sturgeon: American Fisheries Society Symposium 28, Bethesda, Maryland, p. 237-247.

Duke, S., Anders, P., Ennis, G., Hallock, R., Hammond, J., Ireland, S., Laufle, J., Lauzier, R., Lockhard, L., Marotz, B., Paragamian, V.L., and Westerhof, R., 1999, Recovery plan for Kootenai River white sturgeon (Acipenser transmontanus): Journal of Applied Ichthyology, v. 15, p. 157-163.

Kock, T.J., Congleton, J.L., and Anders, P.J., 2006, Effects of sediment cover on survival and development of white sturgeon embryos: North American Journal of Fisheries Management, v. 26, no. 1, p. 134-141.

Markov, K.P., 1978, Adhesiveness of egg membranes in sturgeons (Family Acipenseridae): Journal of Ichthyology, v. 18 , p. $437-446$.

McCabe, G.T., Jr., and Tracy, C.A., 1994, Spawning and early life history of white sturgeon, Acipenser transmontanus, in the lower Columbia River: National Oceanic and Atmospheric Administration, National Marine Fisheries Service Scientific Publication Office, Fishery Bulletin, v. 92, no. 4, p. 760772.
Miller, A.I., and Beckman, L.G., 1996, First record of predation on white sturgeon eggs by sympatric fishes: Transactions of the American Fisheries Society, v. 125, no. 2, p. 338-340.

Paragamian, V.L., Kruse, G., and Wakkinen, V.D., 2001, Spawning habitat of Kootenai River white sturgeon, post-Libby Dam: North American Journal of Fisheries Management, v. 21, no. 1, p. 22-33.

Paragamian, V.L., and Wakkinen, V.D., 2011, White sturgeon spawning and discharge augmentation: Fisheries Management and Ecology, v. 18, no. 4, p. 314-321.

Parsley, M.J., and Beckman, L.G., 1994, White sturgeon spawning and rearing habitat in the lower Columbia River: North American Journal of Fisheries Management, v. 14, no. 4 , p. 812-827.

Parsley, M.J., Beckman, L.G., and McCabe, G.T., 1993, Spawning and rearing habitat use by white sturgeons in the Columbia downstream from McNary Dam: Transactions of the American Fisheries Society, v. 122, no. 2, p. 217-227.

Perrin, C.J., Rempel, L.L., and Rosenau, M.L., 2003, White sturgeon spawning habitat in an unregulated river-Fraser River, Canada: Transactions of the American Fisheries Society, v. 132, no. 1, p. 154-165.

Peterka, J.J., and Kent, J.S., 1976, Dissolved oxygen, temperature, and survival of young fish at spawning sites: U.S. Environmental Protection Agency, EPA-600/3-76/113, Duluth, Minnesota.

Schaffter, R.G., 1997, White sturgeon spawning migrations and the location of spawning habitat in the Sacramento River, California: California Fish and Game, v. 83, p. 1-20.

Scott, W.W., and O’Bier, A.H., 1962, Aquatic fungi associated with diseased fish and fish eggs: The Progressive Fish Culturist, v. 24, no. 1, p. 3-15.

U.S. Fish and Wildlife Service, 1994, Determination of endangered status for the Kootenai River white sturgeon population: Federal Register, v. 59, no. 71, p. 45989.

U.S. Fish and Wildlife Service, 1999, Recovery plan for the Kootenai River population of the white sturgeon (Acipenser transmontanus): U.S. Fish and Wildlife Service, Portland, Oregon [variously paged].

van der Leeuw, B.K., Parsley, M.J., Wright, C.D., and Kofoot, E.E., 2006, Validation of a critical assumption of the riparian habitat hypothesis for white sturgeon: U.S. Geological Survey Scientific Investigations Report 2006-5225, 20 p. (Also available at http://pubs. er.usgs.gov/publication/sir20065225.) 


\section{Glossary}

Egg An unfertilized gamete from a female white sturgeon.

Embryo A fertilized gamete.

Free-swimming embryo An embryo that has hatched and is feeding endogenously off the yolk sac.

Incubator A modified aquarium in which embryos on various substrates were placed. 
Publishing support provided by the U.S. Geological Survey Publishing Network, Tacoma Publishing Service Center

For more information concerning the research in this report, contact the Director, Western Fisheries Research Center

U.S. Geological Survey

6505 NE 65th Street

Seattle, Washington 98115

http://wfrc.usgs.gov/ 
